\title{
Energetic performance of landfill and digester biogas in a domestic cooker
}

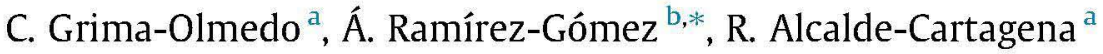 \\ a Escuela Técnica Superior de Ingenieros de Minas, Universidad Politécnica de Madrid, Spain \\ ${ }^{\mathrm{b}}$ BIPREE Research Group, Escuela Técnica Superior de Ingeniería y Diseño Industrial, Universidad Politécnica de Madrid, Spain
}

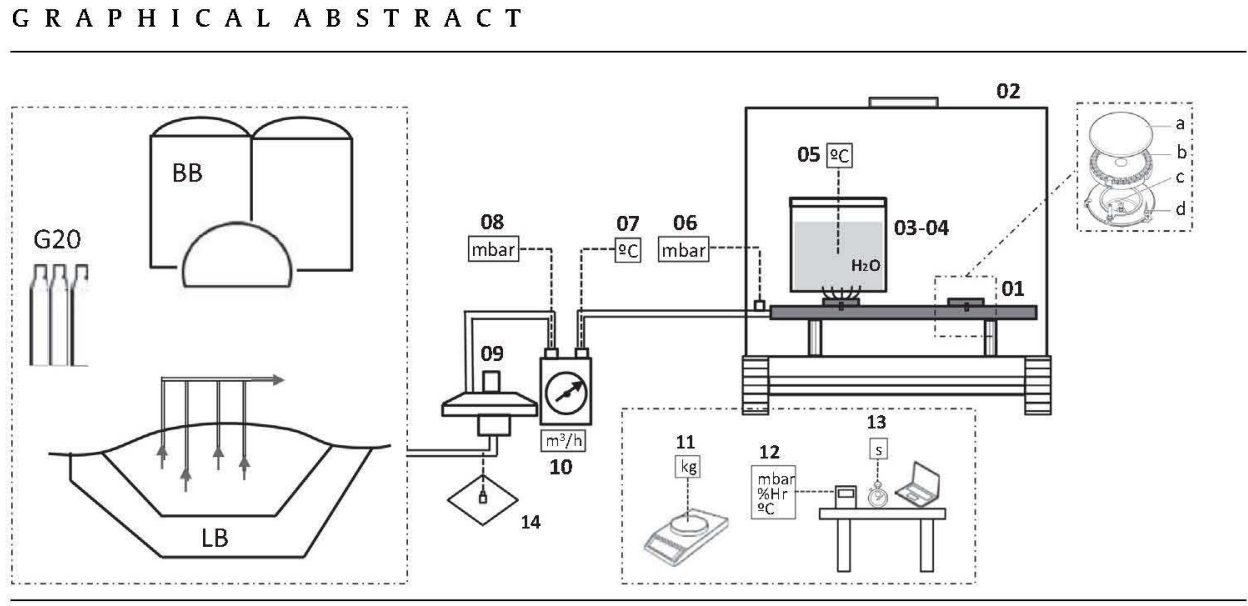

A B S T R A C T

The energetic performance of landfill biogas (LB) and biodigester biogas (BB) from municipal waste was examined in consumption tests. These tests were performed in situ at a gas generation plant associated with a landfill facility in Madrid (Spain) and following the standard UNE-EN 30-2-1 (1999). The jets of a domestic cooker commonly used for natural gas (NG) or liquefied petroleum gas (LPG) were modified to operate with the biogases produced at the facility. The working pressures best suited to the tested gases, i.e., to avoid flashback and flame lift, and to ensure the stability and correct functioning of the flame during combustion, were determined by trial and error. Both biogases returned optimum energetic performance for the transfer of heat to water in a metallic recipient (as required by the above standard) at a supply pressure of 10 mbar. Domestic cookers are normally supplied with NG at a pressure of 20 mbar, at which pressure the energetic performance of G20 reference gas was higher than that of both biogases ( $52.84 \%$ compared to $38.06 \%$ and $49.77 \%$ respectively). Data concerning these issues involving also unexplored feedstock are required for the correct conversions of domestic cookers in order to avoid risks of serious personal injuries or property damages.

\section{Introduction}

The importance of biogas as a primary energy source in Europe has increased strongly in recent years, from 4976 Mtoe in 2006, to

\footnotetext{
* Corresponding author. Tel.: +34 913366837.

E-mail address: alvaro.ramirez@upm.es (Â. Ramírez-Gómez).
}

10,154 Mtoe in 2011 - an increment of $104 \%$. In Europe, over the same period, the production of landfill biogas increased by $3.2 \%$ that obtained from sewage sludge rose by $36.6 \%$, and the production of other types of biogas grew by $351 \%$ [1].

The level of use varies greatly in Europe. There are countries such as Germany, Austria, Denmark and Sweden fairly advanced in their use of biogas, while there are others that still poses a 


\section{Nomenclature}

$Q_{n} \quad$ nominal consume $(\mathrm{kW})$

$V_{n} \quad$ volume of dry gas consumed $\left(\mathrm{m}^{3} / \mathrm{h}\right)$

$H_{s} \quad$ higher calorific value $\left(\mathrm{MJ} / \mathrm{m}^{3}\right)$

$m_{e} \quad$ mass of the water-filled recipient $(\mathrm{kg})$

$T_{1} \quad$ initial water temperature $\left({ }^{\circ} \mathrm{C}\right)$

$\mathrm{T}_{2} \quad$ final water temperature $\left({ }^{\circ} \mathrm{C}\right)$

$V_{c} \quad$ volume of gas consumed, adjusted to standardised conditions $\left(\mathrm{m}^{3}\right)$

$V_{\text {med }} \quad$ volume of gas actually measured by the gas meter $\left(\mathrm{m}^{3}\right)$

$p_{a} \quad$ atmospheric pressure (mbar)

$p \quad$ gas pressure before the jet (mbar)

$p_{w} \quad$ partial pressure of water vapour (mbar)

$t_{g} \quad$ temperature of the gas at the point of consumption $\left({ }^{\circ} \mathrm{C}\right)$

$d_{0} \quad$ jet diameter $(\mathrm{mm})$

$C_{d} \quad$ coefficient of discharge

$s \quad$ relative density biogas
Greek symbol

$\eta_{u} \quad$ energetic performance (\%)

\section{Abbreviations}

LB landfill biogas

BB biodigester biogas

NG natural gas

LPG liquefied petroleum gas

G20 reference gas for European gas groups $\mathrm{H}$ and $\mathrm{E}$ (second family)

G30 reference gas for European gas groups B/P y B (third family)

G31 reference gas for European gas group P (third family)

HHV higher heating value

LHV lower heating value great potential for its development, especially in Eastern Europe [2-5].

Some benefits from the use of biogas are seen from the reduction in the emissions of greenhouse gases [6-9] such as $\mathrm{CO}_{2}, \mathrm{CH}_{4}$, organic volatile compounds and the generation of acid rain, because of the emission of sulphur oxides (SOx) and nitrogen oxides (NOx) to the atmosphere. Other benefits are seen in the by-products from the digestion of the organic matter $[2,10]$. These can be used as natural fertilizers contributing to decrease the use of chemical fertilizers that can have a negative impact by the accumulation of heavy metals on the underground water and the quality of the soil. There are many other potential applications for biogas such as the heat generation, electricity or fuel for vehicles [11-14]. Biogas can be compressed and even distributed through pipelines of NG fulfilling some composition requirements, although some problems of siloxanes for example are still unsolved [15].

Biogas is a type of fuel that is mainly composed of $50-70 \%$ (by volume) methane $\left(\mathrm{CH}_{4}\right)$ and $25-40 \%$ (by volume) carbon dioxide $\left(\mathrm{CO}_{2}\right)$, it may also contain traces of other gases $(1-5 \%)$ such as the hydrogen sulphur, ammoniac, water vapour and volatile organic compounds [16-18]. It is usually produced in landfills or anaerobic digesters, using the organic fraction of urban solid residues, sewage sludge from wastewater treatment plants, animal manure or agro-industrial by-products and residues among others $[2,19,20]$.

There are some alternatives for improving the combustion properties of biogas: mixing it with other fuels with better features or increasing the amount of oxygen in the mixture [21,22]. Biogas enriched with methane (biomethane), eliminating $\mathrm{CO}_{2}$ to adjust the calorific value and relative density in order to meet NG specifications such as the Wobbe Index, can replace NG in its different applications [23]. Main technologies for $\mathrm{CO}_{2}$ removal include pressure swing adsorption and high-pressure water wash, dominating technologies in Europe in 2009, reactive absorption [24,25], membrane separation [26], physical absorption and cryogenic separation.

Biogas that is not enriched with methane has a lower calorific value (CV), low burning velocity and narrower flame-stability limits, mainly due to the high amount of inert gases in its composition that cool down the reactions [27]. However, as it can be produced at any place it poses a high potential for domestic uses such as for cooking in rural areas near the generation place, or in developing countries which could substitute the use of biomass for cooking
[28]. China, India and Nepal have used biogas for cooking for a long time. In fact, China and India have already developed testing methodologies and standards [29-31] on domestic biogas stoves. However, there are others such as Nigeria where biogas technology is unavailable and not used besides the potential applications aforementioned [32].

Biogas stove designs are specifically developed for the lowpressure gas burners from digesters or storage holders containing biogas [33-35]. Traditionally, these digesters have been made of mild steel or clay. Floating drum or fixed dome model digesters have been commonly used [36]. A conduit connects the digester to the stove. Once the gas arrives to the stove, the jet at the inlet of the burner increases the speed of the biogas sucking air (primary air) into the conduit. Then, the conduit is widened reducing its speed arriving at the burner head. Finally, more air (secondary air) is supplied from the surroundings enabling the final combustion [32].

Organic wastes from food industry or agriculture have a great potential but they are well understood and widely adopted for biogas production. However, one unexplored organic waste-based feedstock relates to municipal wastes sorting [37].

In this regard, biogas has a calorific value lower than that of NG, between 16 and $20 \mathrm{MJ} / \mathrm{m}^{3}$, due to the presence of inert compounds but mainly due to the lower content of $\mathrm{CH}_{4}$, which can be as high as $70 \%$ in gas produced from municipal and solid urban wastes. However, it can vary widely, depending on the organic waste from which it is produced; the different nutrient composition (protein, fat, carbohydrates) of the substrates is one of the main reasons for the different methane content [38]. Also the degree of compaction of that material along with its humidity and temperature and $\mathrm{pH}$ [39] have an influence, as well as the gas production method used $[40-42,24,43,26]$ (controlled degasification of landfills, anaerobic digestion, etc.).

The requirement for any type of combustible gas is to have a stable flame. In this regard when biogas is burnt in a conventional burner it presents some difficulties in comparison with NG or LPG due to the higher content of $\mathrm{CO}_{2}$ [44-47]. Studies carried out on the flame stability in burners with biogas, obtained pre-mixing natural gas from the network, $\mathrm{CO}_{2}(30-40 \%)$ and air, indicate that the lower the content of $\mathrm{CH}_{4}$ and the higher content in $\mathrm{CO}_{2}$, the lower the stability of the flame is. As a consequence, the velocity of the flame was lower being more prone to be produced the detachment of the flame. When the diameter of the jet of biogas is lower, is 
produced a decrease of the zone of stable combustion of the flame, however is more difficult to produce the detachment of the flame. On the other hand, an increase of the temperature of supply of biogas produces a higher velocity of combustion and a wider area where the flame is stable [48].

The combustion efficiency of biogas depends on the use made of its $\mathrm{CV}$. Good combustion efficiency demands appropriate $\mathrm{O}_{2}$ and $\mathrm{CO}_{2}$ contents in the final combustion mixture, an appropriate starting temperature, and good flame stability at the burner. Raising the $\mathrm{O}_{2}$ content in the combustion mixture from $21 \%$ to $27 \%$ improves energetic performance by reducing the negative effects of $\mathrm{CO}_{2}$ [48]. Too much $\mathrm{CO}_{2}$ (35-45\%) in the combustion mixture can lead to a flickering yellow flame indicative of poor combustion [49]. Finally, the higher the gas mix temperature prior to combustion, the greater its energetic performance [50].

As suggested by the European Harmonization Of Natural Gas Quality Workgroup (mandate to CEN for standardization in the field of gas qualities) [51], it is vital that gas - including biogas quality, and how this affects the functioning of appliances, be understood if we are to satisfy consumer demands. The most important parameters to optimize are: gas/air mixing rate, flame speed, ignition temperature and pressure of inlet biogas, which are influenced by the diameter of the jet [32]. Pressure of inlet biogas and jet diameter were also the object of this work. The energetic performance of two types of biogas, one biogas from a landfill and other from an anaerobic digester, using a domestic cooker commonly used for NG or LPG was examined.

\section{Materials and methods}

\subsection{Gases and experimental apparatus}

Two types of biogas were examined in this work LB and BB. Their energetic performances were compared to that of gas G20, i.e., the reference gas for European gas groups $\mathrm{H}$ and $\mathrm{E}$ [52], used in tests for the certification of gas appliances. Table 1 shows the composition of these gases as determined by the gas chromatography technique set out in standards UNE-EN 437 (2009) [53], ISO 6976 (1995) [54] and ISO 6141 (2007) [55].

The gases were subjected to consumption tests according to standard UNE-EN 30-2-1 (1999) [52]. These were performed using an installation consisting of a domestic cooker with connections for the use of biogas, plus the regulating and measuring devices shown in Fig. 1 (see Table 2 for descriptions of the numbered parts). As required, the cooker was connected to the landfill biogas supply for the provision of $\mathrm{LB}$, to a digestor for the provision of $\mathrm{BB}$, and to bottles for the provision of G20. Tests involving the biogases were performed at a gas-producing landfill in the Province of Madrid, Spain; tests with G20 were performed at the Laboratorio Oficial J.M. Madariaga ${ }^{1}$ (Madrid, Spain).

The boxed area on the left of Fig. 1 shows the origins of the different gas types. These are shown in more detail in Fig. 2. Fig. $2 a$ shows the landfill aperture valve, through which the LB flowed into the experimental system. Fig. 2b shows the supply connections on the digester; the outflowing $\mathrm{BB}$ passed through a water condensing system to dry the gas before reaching the experimental system. Fig. 2c shows the connections and regulation system for the G20 gas.

The cooker had three gas burners: an auxiliary burner (A), a semi-rapid burner (SR), and a rapid burner (R), plus an electric plate (Fig. 3). Only burner A was used - fully open - in the gas

\footnotetext{
1 Gas appliance test laboratory. Accreditation ENAC no 22/LE1962, meeting the requirements laid out in standard UNE-EN ISO/IEC 17025; 2005 (CGA-ENAC-LEC).
}

Table 1

Properties of the gases examined.

\begin{tabular}{lcll}
\hline Composition & Landfill biogas & Biodigestor biogas & $\mathrm{G}^{\mathrm{a}}$ \\
\hline $\mathrm{CH}_{4}(\%)$ & 51.45 & 66.35 & 100 \\
$\mathrm{HHV}\left(\mathrm{MJ} / \mathrm{m}^{3}\right)^{\mathrm{b}}$ & 20.52 & 26.45 & 37.78 \\
$\mathrm{LHV}\left(\mathrm{MJ} / \mathrm{m}^{3}\right)^{\mathrm{b}}$ & 18.49 & 23.8 & 34.02 \\
Relative density & 0.945 & 0.870 & 0.555 \\
$\mathrm{CO}_{2}(\%)$ & 34.2 & 32.75 & - \\
$\mathrm{O}_{2}(\%)$ & 2.05 & 0.15 & - \\
$\mathrm{N}_{2}(\%)$ & 12.1 & 0.6 & - \\
\hline
\end{tabular}

All values determined at $15{ }^{\circ} \mathrm{C}$ and $101,325 \mathrm{kPa}$, according to standards UNE-EN 437

(2009), ISO 6976 (1995) and ISO 6141 (2007).

a G20: Reference gas, UNE-EN 30-2-1: 1999.

b HHV: higher heating value, LHV: lower heating value.

consumption tests. The cooker was protected from wind currents by a wind-breaking cowling (label 02 in Fig. 1 and Table 2).

\subsection{Gas consumption tests}

The three gases were subjected to consumption tests according to standard UNE-EN 30-2-1 (1999) [52]. For each gas, $3.7 \mathrm{~kg}$ of water were first heated in a $220 \mathrm{~mm}$-diameter aluminium recipient (density $2700 \mathrm{~kg} \mathrm{~m}^{-3}$; wall thickness $3.0 \mathrm{~mm}$ ) for $10 \mathrm{~min}$ to stabilise the burner and to ensure optimum running conditions, i.e., for the copper jet (thermal dilation coefficient $1.7 \times$ $10^{-5}{ }^{\circ} \mathrm{C}^{-1}$ ) to reach a constant aperture, thus allowing a constant flow of gas. The recipient was then exchanged for another (density $2700 \mathrm{~kg} \mathrm{~m}^{-3}$; wall thickness $3.5 \mathrm{~mm}$ ) containing $3.7 \mathrm{~kg}$ of water at $20 \pm 1{ }^{\circ} \mathrm{C}$ (T1). This was then heated to $90 \pm 1{ }^{\circ} \mathrm{C}$ (T2). The volume of gas required to heat this vessel through these $70^{\circ} \mathrm{C}$ was recorded by the in-line gas meter.

Each biogas was tested over a range of supply pressures between flashback and flame lift to determine the optimum pressure, as denoted by the lowest gas consumption. For the LB this range was $7-13$ mbar, and for $B B \quad 7-20$ mbar (see jet diameters below). These pressure ranges were determined by trial and error. Similar pressure ranges were also found in studies from other authors (7.5-16 mbar and 7-20 mbar, respectively) [56,57]. The G20 gas was tested between $18-22$ mbar (i.e., allowing for slight variation around the 20 mbar dictated by standard UNE-EN 30-21 (1999) [52]. Pressures were changed using the in-line regulator (label 10 in Fig. 1 and Table 2).

The amount of energy supplied to the water by each gas $\left(Q_{n}\right)$ was calculated according to standards UNE EN-30-1-1 (2009)+A2 (2011) [58] and UNE EN 437:2003+A1 (2009) [53] as required by Directive 2009/142/CE Gas Appliances:

$Q_{n}=0.278 \cdot V_{n} \cdot H_{s}$

The energetic performance of the gases was determined as shown below [52]:

$\eta_{u}=\frac{4.186 \cdot m_{e} \cdot\left(T_{2}-T_{1}\right)}{10 \cdot V_{c} \cdot H_{s}}$

and where $V_{c}$ is calculated as follows [52]:

$V_{c}=V_{\text {med }} \cdot \frac{p_{a}+p-p_{w}}{1023.25} \cdot \frac{288.15}{273.15+t_{g}}$

\subsection{Jet diameters}

For adequate flame stability, the diameter of the jet must be appropriate. If it is too small, combustion will not occur; if it is too big, the flame will be unstable and flashback may occur [50]. A blue flame generally indicates correct combustion. Larger jet diameters than normal had to be used with the biogases. A range 


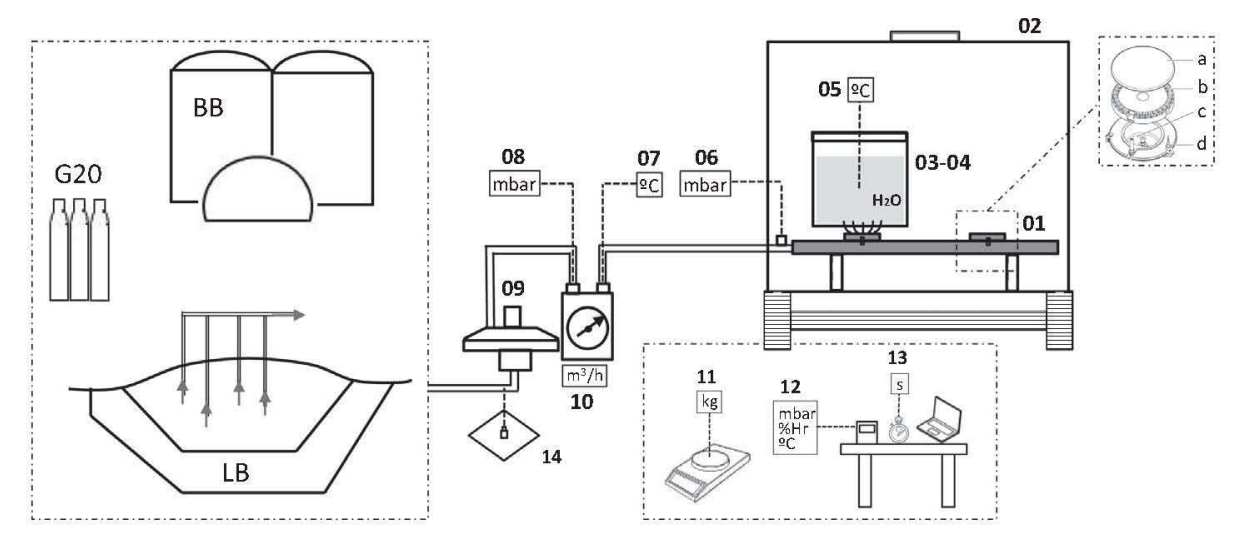

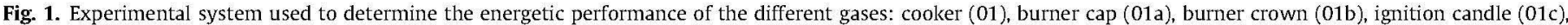

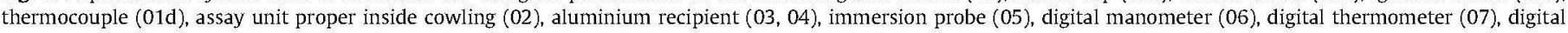
manometer (08), gas regulator (09), gas flow meter (10), electronic balance (11), meteorological station (12), chronometer (13), Tedlar bag (14).

Table 2

Elements making up the experimental system.

\begin{tabular}{|c|c|c|c|c|}
\hline $\begin{array}{l}\text { Label in } \\
\text { Fig. } 1\end{array}$ & Device & Apparatus model & $\begin{array}{l}\text { Units of measurement/other } \\
\text { properties }\end{array}$ & Function \\
\hline 01 & Cooker & - & - & - \\
\hline 02 & $\begin{array}{l}\text { Assay unit proper inside } \\
\text { cowling }\end{array}$ & - & - & - \\
\hline 03 & Aluminium recipient & - & $3.7 \mathrm{~kg}$ in a $220 \mathrm{~mm}$ diameter & $\begin{array}{l}\text { For heating water to stabilise the burner at optimum running } \\
\text { conditions }\end{array}$ \\
\hline 04 & Aluminium recipient & - & $3.7 \mathrm{~kg}$ in a $220 \mathrm{~mm}$ diameter & For heating water \\
\hline 05 & Immersion probe & $\begin{array}{l}\text { Fluke } 52 \text { II } \\
\text { Thermometer }\end{array}$ & $0-1300^{\circ} \mathrm{C}$ & For heating water \\
\hline 06 & Digital manometer & Comark & $0-140 \mathrm{mbar}$ & For measuring the gas supply pressure \\
\hline 07 & Digital thermometer & Testo 701 & $-200 / 800^{\circ} \mathrm{C}$ & For measuring the gas supply pressure \\
\hline 08 & Digital manometer & Digitron & $0-130$ mbar & For measuring the gas supply pressure \\
\hline 09 & Gas regulator & Actaris Delta $2050 / \mathrm{A}$ & - & For measuring the gas supply pressure \\
\hline 10 & Gas flow meter & Elster Amco & $10-100001 / \mathrm{h}$ & For measuring gas consumption \\
\hline 11 & Electronic balance & $\begin{array}{l}\text { Sartorios Basic Plus } \\
12000-5\end{array}$ & $0-12 \mathrm{~kg}$ & For measuring the mass of the water \\
\hline 12 & Meteorological station & PCE-THB 40 & Mbar, $\% \mathrm{HR}$, and ${ }^{\circ} \mathrm{C}$ & $\begin{array}{l}\text { For measuring temperature, atmospheric pressure, and } \\
\text { relative humidity }\end{array}$ \\
\hline 13 & Chronometer & Casio HS-5 & $1 / 100 \mathrm{~s}-10 \mathrm{~h}$ & For measuring heating time \\
\hline 14 & Tedlar bag & Tedlar & 11 & For gas analysis \\
\hline
\end{tabular}

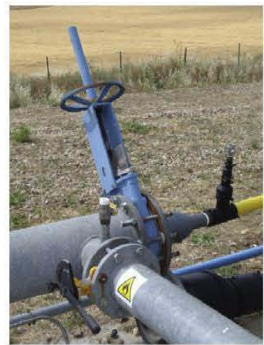

(a)

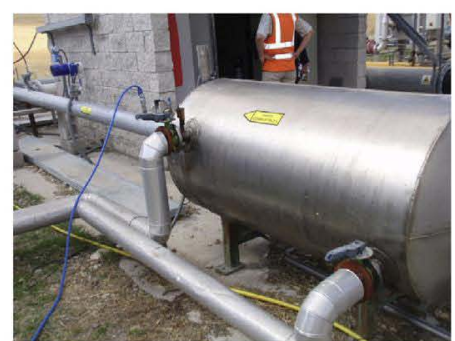

(b)

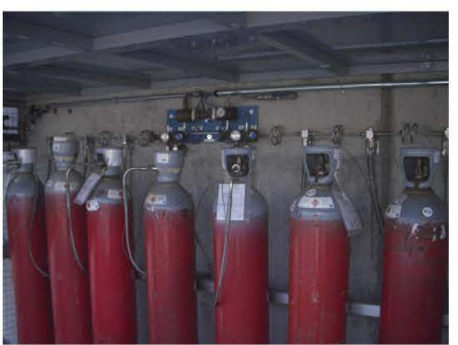

(c)

Fig. 2. Gas supply systems: (a) LB aperture valve, (b) BB water condensing system and (c) G20 gas bottles.

of outlet sizes (Table 3) was prepared, and the most appropriate size, i.e., that which provided a stable flame, chosen by trial and error (Fig. 4), and according to the American Gas Association (AGA) test procedure [59]. The jet sizes obtained by trial and error were also compared with those obtained using calculations such as in Fulford [33].

Since the jet diameters chosen for the biogases were wider (LB $1.9 \mathrm{~mm}, \mathrm{BB} 1.46 \mathrm{~mm}$ ) than for the $\mathrm{G} 20$ (factory set at $0.70 \mathrm{~mm}$ ), the tested pressures had to be lower. These wider jet diameters were required since the biogases had a lower $\mathrm{CV}$ - partly because their $\mathrm{CH}_{4}$ contents are lower (BB 51.45\% and LB 66.35\% lower than $\mathrm{G} 20$ ), and partly because they have more $\mathrm{CO}_{2}$ in their mix (BB $34.2 \%$ and LB $32.75 \%$ greater than G20). Given the lower CVs of the biogases, the cooker flame sensor (the job of which is to prevent the flow of gas to the jet when a flame is absent) had to be decommissioned. 


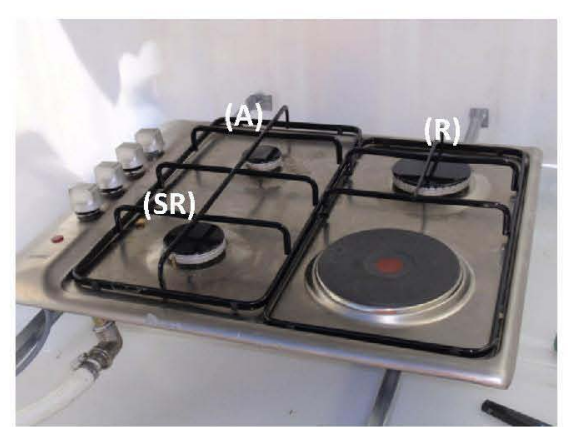

Fig. 3. The cooker gas burners and electric plate. Auxiliary burner (A), semi-rapid burner (SR), and rapid burner (R).

\section{Results and discussion}

\subsection{Energetic performance}

The coefficient of variation of the energetic performance of G20 at $20 \mathrm{mbar}$, of BB at $15 \mathrm{mbar}$, and of $\mathrm{LB}$ at $10 \mathrm{mbar}$ (i.e., tests for which three repetitions were performed) was low. This suggests that the results of the remaining tests performed with fewer replicas were reliable. No more replicas could be performed for these tests in the field given the operating constraints of the gasproducing facility.

In this research work it was searched for the optimal supply pressure for LB and BB. Some standards or codes such as American Gas Association Flame Code define it as the achievement of a flame with inner cones rounded and soft tips (Code 0 ). In the case of the LB the optimal supply pressure was found between 7 and $13 \mathrm{mbar}$ for LB. Out of this range it was observed that several sectors of the flame blown out. In the case of the BB, the optimal supply pressure was found in a wider range, between 7 and 20 mbar. In this case, the flame did not blow out at the lower and higher pressure tested, which is explained by the content of $\mathrm{CH}_{4}$ in the $\mathrm{BB}$, higher than that in the LB, which affects to the combustion process.

Fig. 5 shows that the energetic performance of G20 was about $52 \%$ at all the tested pressures. This agrees with the requirements of the European standard UNE-EN 30-2-1: 1999 [52] that requires energetic performance of domestic cookers as equal or higher than $52 \%$.

It should be noted that in some standards such as the Indian, Chinese and Kenya standards the efficiency required for biogas domestic cookers is $55 \%[29,35,60]$. These differences found between standards in the energetic performance are due to different parameters considered in their calculations such as the standard temperature of the gas $\left(0^{\circ} \mathrm{C}\right.$ in the Indian and Chinese standard, $27^{\circ} \mathrm{C}$ in the Kenya standard and $15^{\circ} \mathrm{C}$ in the European standard), or the type of calorific value considered (gross or net).

The design of a conventional domestic cooker of NG or LPG, as used in this study, is slightly different from the typical stoves for biogas [60]. The main differences are found in the design of the burner and the pre-mixing process of the biogas with the air (primary air) that is carried out along a conduit to achieve a more homogeneous mix of the fuel with oxygen [33].

The highest energetic performance for $\mathrm{BB}$, using a domestic cooker designed for NG or LPG, was about $4.4 \%$ lower and was obtained at a pressure of $10 \mathrm{mbar}$. The highest energetic performance of LB was $31.7 \%$ lower than that of G20; this was also obtained at 10 mbar. The reason for the lower energetic performance of LB is likely to be the greater heterogeneity of the material from which it is produced, leading to fluctuations in $\mathrm{CH}_{4}$ content.

Both $\mathrm{BB}$ and $\mathrm{LB}$ returned the highest energetic performance at a supply pressure of 10 mbar. Knowing this figure is important if the highest energetic performance is to be obtained. If the supply pressure were below optimum, the energy in the gas would not be transferred efficiently to an object to be heated (the water in the present case). If the pressure were too high, the flame would pass rapidly around the object, and there would be insufficient time for the energy in the flame to be transferred.

The energetic performance of LB is also lower comparing with the results obtained from other authors using biogas domestic cookers (see Table 4) [61]. However, the energetic performance of BB was similar as in the study report on efficiency measurement of biogas, kerosene and LPG stoves developed at the Tribhuvan University [62]. Results of $49.44 \%, 43.8 \%$ and $32.26 \%$ for perfectly controlled, semi-controlled and uncontrolled conditions were found using biogas with a calorific value of $22 \mathrm{MJ} / \mathrm{m}^{3}$ and a similar methodology to determine the energetic performance. In this case results vary because the efficiency of a given domestic cooker is not constant, due to it could vary on the basis of surrounding conditions and quality of fuel used.

The Netherlands Development Organisation (SNV) commissioned three institutes, namely Chengdu Energy Environment International Cooperation (CEEIC), Chengdu in line with Biogas Appliances Quality Inspection Center of the Ministry of Agriculture, People's Republic of China; Department of Renewable Energy Sources (DRES), College of Technology and Engineering, Maharana Pratap University of Agriculture and Technology, Udaipur, India; and Kiwa Gastec Certification (GASTEC), Apeldoorn, The Netherlands to test biogas stoves obtained from eight countries (Bangladesh, Cambodia, Ethiopia, India, Lesotho, Nepal, Rwanda and Vietnam). CEEIC followed a testing procedure prescribed in the

Table 3

Consumption and energetic performance of the different gases at different supply pressures.

\begin{tabular}{|c|c|c|c|c|c|c|}
\hline GAS & $\begin{array}{l}\text { Injector outlet } \\
\text { diameter (mm) }\end{array}$ & $\begin{array}{l}\text { Supply pressure } \\
\text { (mbar) }\end{array}$ & $\begin{array}{l}\text { Consumption } \\
(\mathrm{kW})\end{array}$ & $\begin{array}{l}\text { Energetic performance }(\%) \pm \text { uncertainty } \\
\text { introduced by the apparatus used }\end{array}$ & $\begin{array}{l}\text { No of replicas } \\
\text { performed }\end{array}$ & $\begin{array}{l}\text { Coeff. variation of energetic } \\
\text { performance }\end{array}$ \\
\hline \multirow[t]{5}{*}{ G20 } & 0.70 & 18 & 0.83 & $52.85 \pm 0.05$ & 1 & - \\
\hline & & 19 & 0.92 & $51.11 \pm 0.05$ & 2 & 2.40 \\
\hline & & 20 & 1.01 & $52.84 \pm 0.05$ & 3 & 0.61 \\
\hline & & 21 & 1.09 & $52.05 \pm 0.05$ & 1 & - \\
\hline & & 22 & 1.19 & $52.91 \pm 0.05$ & 1 & - \\
\hline \multirow[t]{5}{*}{ BB } & 1.46 & 7 & 1.30 & $48.15 \pm 0.05$ & 1 & - \\
\hline & & 10 & 1.65 & $49.77 \pm 0.05$ & 2 & 0.66 \\
\hline & & 13 & 1.88 & $48.01 \pm 0.05$ & 1 & - \\
\hline & & 15 & 1.93 & $44.40 \pm 0.05$ & 3 & 1.58 \\
\hline & & 20 & 2.47 & $44.47 \pm 0.05$ & 1 & - \\
\hline \multirow[t]{3}{*}{ LB } & 1.90 & 7 & 0.72 & $35.75 \pm 0.04$ & 1 & - \\
\hline & & 10 & 1.49 & $38.06 \pm 0.04$ & 3 & 0.47 \\
\hline & & 13 & 1.64 & $36.23 \pm 0.04$ & 1 & \\
\hline
\end{tabular}




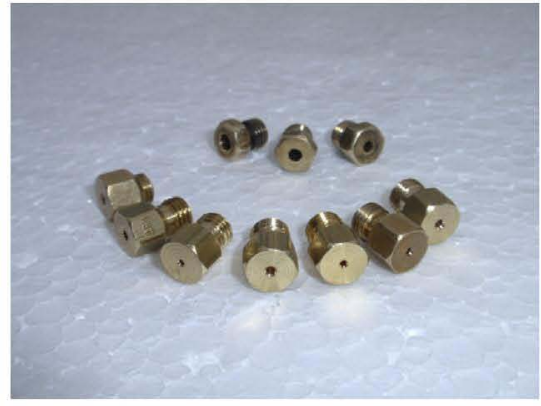

(a)

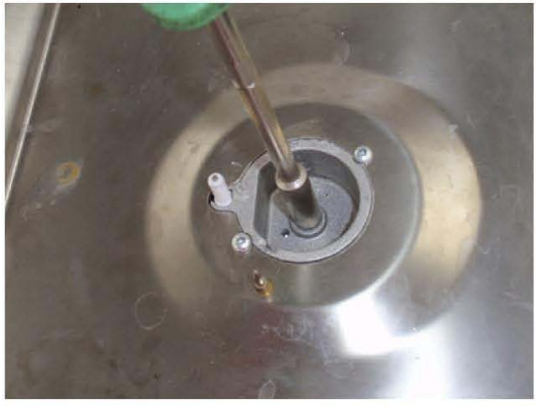

(b)

Fig. 4. (a) Original (bottom row) and recalibrated (top row) injector outlets and (b) mounting the injector outlet in a gas burner.

ENERGETIC PERFORMANCE

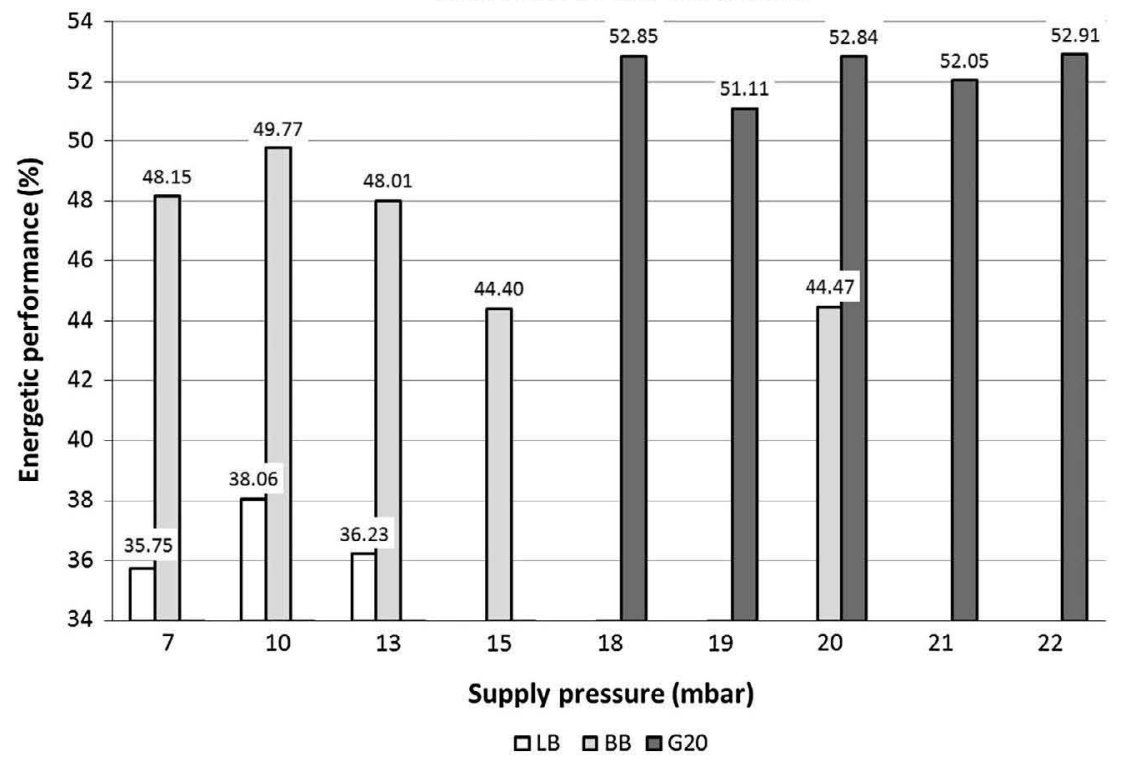

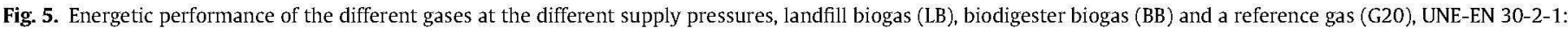
1999 .

Table 4

Efficiencies of different types of stoves.

\begin{tabular}{lll}
\hline Stove & Combustion efficiency\% & Overall efficiency \% \\
\hline Biogas & 99.4 & $45-57.4$ \\
LPG & 97.7 & 53.6 \\
Kerosene & 96.5 & 49.5 \\
Wood & 90.1 & 22.8 \\
\hline
\end{tabular}

Source: Tumwesige et al. (2014), Sasse et al. (1991), APCAEM (2007) and Smith et al. (1993).

Chinese standard specifications for biogas stoves. DRES used the procedure described in the Indian standard specification and GASTEC developed its own methodology. The mean energetic performance in biogas cooking stoves in these countries was between $30.6 \%$ and $59.3 \%$ (at standard conditions of $0{ }^{\circ} \mathrm{C}$ and $760 \mathrm{mmHg}$ ). Extreme values of about $20 \%$ and also almost $90 \%$ were also found in studies from other authors [32,56]. There is a great variety of types of cooking stoves where different problems were identified in the stoves such as position non-centred of the jet hole, non-uniform size of burner ports, no gas tap, big air-intake size and so on.

The present research work shows that if the calorific value of the biogas is high as it can be in an anaerobic digester using sorted municipal waste a NG or LPG domestic cooker may provide enough energetic performance if proper jets and pressure is supplied as it is discussed below.

\subsection{Jet diameters}

The jet diameters obtained for $\mathrm{LB}$ and $\mathrm{BB}$ were $1.9 \mathrm{~mm}$ and $1.46 \mathrm{~mm}$ respectively. This research work provides useful information for the conversion of cooking stoves commonly used for NG or LPG to biogas.

Other authors obtained the jet diameters through calculations such as Fulford [33] or Itodo et al. [32]. For the sake of comparison the Eq. (4) has been also used as in Fulford [33]:

$d_{0}=\sqrt{\frac{Q_{n}}{0,036 \cdot C_{d}}} \cdot \sqrt[4]{\frac{s}{p}}$

To use this formula it has been considered that the gas burner is of $1 \mathrm{~kW}$ and the energetic performance of $55 \%$. The discharge coefficient of the jet (Cd) was 0.9 and the biogas pressure 10 mbar in the inlet. Diameters of $1.48 \mathrm{~mm}$ and $1.75 \mathrm{~mm}$ were determined with a nominal consume of $0.24 \mathrm{~m}^{3} / \mathrm{h}$ for $\mathrm{BB}$ and $0.32 \mathrm{~m}^{3} / \mathrm{h}$ for $\mathrm{LB}$, respectively.

The jet diameter experimentally obtained for $\mathrm{BB}(1.46 \mathrm{~mm})$ was very similar. In the case of $\mathrm{LB}(1.90 \mathrm{~mm})$ the determined jet 
diameter was slightly lower; this difference could be explained because of the lower homogeneity and control of the biogas that is extracted from the landfill or also due to the less stable combustion process, as a consequence of the lower content in methane.

It is a common practice in industry to standardize jets when gases are interchangeable. Although in the interchangeability of gases should be considered different properties such as, for example, the laminar burning velocity, the Wobbe Index is considered an important gas interchangeability parameter, being incorporated into most international gas quality specifications [63]. The Wobbe Index (defined as higher calorific value/square root of relative density) is a key indicator of the interchangeability of fuel gases. This index is used to compare the combustion energy output of fuel gases with different composition in an appliance (fire, cooker, etc.). If two fuels have identical Wobbe Indices then for a given pressure and jet diameter the energy output will also be identical. By imposing an upper and lower bound on the Wobbe Index, NOX and other emissions can be controlled, high efficiency of burners can be achieved, and most importantly, the safe operation of equipment can be assured.

An increase in the Wobbe Index of a gas supply will lead to an increase of the thermal energy input into an appliance. A decrease of the Wobbe Index may lead to burner combustion instabilities with potential flame lift and increased CO emissions.

The Wobbe Index range specified in the national regulations of a selection of major European gas consuming countries (Belgium, Denmark, France, Germany, Ireland, Italy, Portugal, Spain and United Kingdom) range from 6.5\%, the lowest value register for Portugal, until 19.5\% the highest value registered by Germany. The European Association for Streamlining of Energy Exchange (EASEE) that with the European Committee for Standardization (CEN), and the support of the European Commission, are forming specifications and Standards to implement the appropriate gas-related European Directives, establishes that the Wobbe Index should vary up to $14.9 \%$ to ensure that the efficiency, reliability and safety of gas-fired equipment will not be compromised [64].

Three "families" of fuel gases have been internationally agreed based also on Wobbe Index. Family 1 involves manufactured gases, Family 2 involves natural gases (high and low ranges) and Family 3 involves liquefied petroleum gas (Table 5).

In Table 6 can be seen an example for G30 and G31, they belong to the same family (third family), according to their Wobbe Index that range between 72.9 and 87.3 and are interchangeable, giving a similar performance using the same appliances [53].

In the case of the present biogases, although they belong to the same family (primary family) due to their Wobbe Indices are between 22.4 and 24.8 , they were not found interchangeable. In order to check this, test were carried out interchanging jets. Tests were carried out for LB with jets $1.91 \mathrm{~mm}$ diameter and BB with jets $1.46 \mathrm{~mm}$ diameter, and during tests they did not perform similarly; not only that the combustion of the flame was not achieved. On the other hand, as is observed for G30 and G31 there is a difference of about $13 \%$ in the Wobbe Indices (at different pressures), while this difference for LB and BB is about 30\%, that is almost triple. This could be seen as an indication of the different behaviour of both of them.

In order to achieve the interchangeability of biogases, these could be blended with another gas, e.g. propane $\left(\mathrm{C}_{3} \mathrm{H}_{8}\right)$ or butane $\left(\mathrm{C}_{4} \mathrm{H}_{10}\right)$ to achieve a Wobbe Index below $15 \%$. In this regard, the use of propane would be preferable; butane hinders proper mixing of gases due to the higher relative density [65]. In order to achieve a good combustion special care should be taken when interchanging gases. Dai et al. [50] concluded from their experiments that yellow-typing and incomplete combustion could come out if the adjustment gas of NG is replaced by LB-LPG mixed gases even though they have an equivalent Wobbe Index.
Table 5

Woobe Index of different gases.

\begin{tabular}{lll}
\hline Family & Wobbe Index $\left(\mathrm{MJ} / \mathrm{m}^{3}\right)$ & \\
\cline { 2 - 3 } & Min & Max \\
\hline First family & 22.4 & 24.8 \\
Second family & 39.1 & 54.7 \\
Third family & 72.9 & 87.3 \\
\hline
\end{tabular}

UNE-EN 437: 2003+A1: 2009. Test gases. AENOR, 2009.

Table 6

Classification of gases.

\begin{tabular}{lllrll}
\hline $\begin{array}{l}\text { Gas } \\
\text { type }\end{array}$ & $\begin{array}{l}\emptyset \\
(\mathrm{mm})\end{array}$ & $\begin{array}{l}\text { Supply pressure } \\
(\mathrm{mbar})\end{array}$ & $\begin{array}{l}\mathrm{HHV} \\
\left(\mathrm{MJ} / \mathrm{m}^{3}\right)\end{array}$ & $\begin{array}{l}\text { Relative } \\
\text { density }\end{array}$ & $\begin{array}{l}\text { Wobbe index } \\
\left(\mathrm{MJ} / \mathrm{m}^{3}\right)\end{array}$ \\
\hline LB & 1.9 & 10 & 20.52 & 0.945 & 21.11 \\
BB & 1.46 & 10 & 26.45 & 0.87 & 28.36 \\
G20 & 0.7 & 20 & 37.78 & 0.555 & 50.72 \\
G30 & 0.51 & 29 & 125.81 & 2.075 & 87.33 \\
G31 & 0.51 & 37 & 95.65 & 1.55 & 76.84 \\
\hline
\end{tabular}

LB: landfill biogas, BB: biodigester biogas, G20-G30-G31: reference gases (UNE-EN 30-2-1: 1999).

$\emptyset$ : injector outlet diameter.

HHV: higher heating value.

Although jet diameters were found for these specific biogases, recommendations for the conversion of cooking stoves were not found in the literature. More tests with biogases of different composition and origin should be carried out in order to shed light on recommendations for its conversion. Further research, should be also carried out on corrosion resistance of burner crowns and pan supports due to the effect of burning of $\mathrm{H}_{2} \mathrm{~S}$, whose concentration is generally high in biogases.

\section{Conclusions}

The energetic performance of the biogases (LB and BB) differed, with $\mathrm{BB}$ returning the highest value. Biogases can be combusted by domestic cookers commonly used for NG or LPG, but the size of the jet diameter must be appropriately adjusted. In this research work the jet diameter of $1.9 \mathrm{~mm}$ for $\mathrm{LB}$ and $1.46 \mathrm{~mm}$ for $\mathrm{BB}$ were found optimal for its combustion. The optimum supply pressure for both the $\mathrm{LB}$ and $\mathrm{BB}$ was $10 \mathrm{mbar}$ compared to the $20 \mathrm{mbar}$ for $\mathrm{G} 20$. The $\mathrm{CH}_{4}$ content of biogas would appear to condition the range of supply pressures at which a stable flame can be produced; the lower the $\mathrm{CH}_{4}$ content, the narrower the range. Furthermore, the difference for $L B$ and BB in the Wobbe Index was about $34 \%$ which means that are not interchangeable. In order to achieve the interchangeability, these should be blended with another gas such as propane or butane. These findings may be useful for the conversion of cooking stoves for NG or LPG to biogas from municipal waste.

\section{Acknowledgements}

This work was funded by project AGL-2012-39994-C03-02 (Spanish Plan for Research, Development and Innovation).

\section{References}

[1] <http://www.eurobserv-er.org>

[2] Budzianowski WM. Sustainable biogas energy in Poland: prospects and challenges. Renew Sust Energy Rev 2012;16(1):342-9.

[3] Budzianowski WM, Chasiak I. The development of biogas fuelled power plants in Germany during the 2001-2010 decade: main sustainable conclusions for Poland. J Power Technol 2011;91(2):102-13.

[4] Budzianowski WM. Opportunities for bioenergy in Poland: biogas and solid biomass fuelled power plants. Rynek Energii $2011 ; 94(3): 138-46$. 
[5] Cvetković S, Radoičić TK, Vukadinović B, Kijevčanin M. Potentials and status of biogas as energy source in the Republic of Serbia. Renew Sust Energy Rev 2014;31:407-16

[6] Ding W, Hewen N, Jinsong C, Jun D, Yang W. Influence of household biogas digester use on household energy consumption in a semi-arid rural region of northwest China. Appl Energy 2012;97:16-23.

[7] Smyth BM, Smyth H, Murphy JD. Determining the regional potential for a grass biomethane industry. Appl Energy 2011;88:2037-49.

[8] Streets DG, Waldhoff ST. Greenhouse-gas emissions from biofuel combustion in Asia. Energy 1999;24(10):841-55.

[9] Bhattacharya SC, Abdul Salam P, Sharma M. Emissions from biomass energy use in some selected Asian countries. Energy 2000;25(2):169-88.

[10] Walekhwa PN, Mugisha J, Drake L. Biogas energy from family-sized digesters in Uganda: critical factors and policy implications. Energy Policy $2009 ; 37: 2754-62$

[11] Bruce N, Perez-Padilla R, Albalak R. Indoor air pollution in developing countries: a major environmental and public health challenge. Bull World Health Organ 2000;78:1078-92.

[12] Gaul M. A comparative study of small-scale rural energy service pathways for lighting, cooking and mechanical power. Appl Energy 2013;101:376-92.

[13] Namuli R, Jaumard B, Awasthi A, Pillay P. Optimisation of biomass waste to energy conversion systems for rural grid-connected applications. Appl Energy 2013;102:1013-21.

[14] Battistoni M, Grimaldi CN. Numerical analysis of injector flow and spray characteristics from diesel injectors using fossil and biodiesel fuels. Appl Energy 2012;97:656-66.

[15] Goldemberg J, Coelho ST. Renewable energy-traditional biomass vs. modern biomass. Energy Policy 2004;32:711-4.

[16] Tsai WT. Bioenergy from landfill gas (LFG) in Taiwan. Renew Sust Energy Rev 2007:11:331-44

[17] Igoni AH, Ayotamuno MJ, Eze CL, Ogaji SOT, Probert SD. Designs of anaerobic digesters for producing biogas from municipal solid-waste. Appl Energy $2008 ; 85(6): 430-8$.

[18] Rajendran K, Kankanala HR, Martinsson R, Taherzadeh MJ. Uncertainty over techno-economic potentials of biogas from municipal solid waste (MSW): a case study on an industrial process. Appl Energy 2014;125:84-92.

[19] IDAE. Plan de Energías Renovables 2011-2020. Ministerio de industria, turismo y comercio. Borrador Julio; 2011.

[20] Kafle GK, Kim SH. Anaerobic treatment of apple waste with swine manure for biogas production: batch and continuous operation. Appl Energy 2013;103:61-72.

[21] Holm-Nielsen JB, Al Seadi T, Oleskowicz-Popiel P. The future of anaerobic digestion and biogas utilization. Bioresour Technol 2009;100(22):5478-84.

[22] Karim GA, Wierzba I, Al-Alousi Y. Methane-hydrogen mixtures as fuels. Int J Hydrogen Energy 1996;21(7):625-31.

[23] Burkhardt M, Busch G. Methanation of hydrogen and carbon dioxide. Appl Energy 2013;111:74-9.

[24] Zhanguang L, Hongguang Z, Wang B, Yalei Z. Effect of ratios of manure to crop on dry anaerobic digestion for biogas production. Trans CSAE $2009 ; 25(4): 196-200$

[25] Song L, Deng L, Yong Y, Xiaodong P, Zhiyong W. Biogas production potential of manure sheep, duck and rabbit for anaerobic digestion and their characteristics. Trans CSAE 2010;26(10):277-82.

[26] Lehtom KA, Huttunen S, Rintala J. Laboratory investigations on co-digestion of energy crops and crop residues with cow manure for methane production: effect of crop to manure ratio. Resour Conserv Recycl 2007;51(3):591-609.

[27] Srinivasan S. Positive externalities of domestic biogas initiatives: implications for financing. Renew Sust Energy Rev 2008:12:1476-84.

[28] Collins O, Pindozzi S, Faugno S, Boccia L. Development of bioenergy technologies in Uganda: a review of progress. Renew Sust Energy Rev 2013;18:55-63.

[29] NSDBS. National Standard of the People's Republic of China on Domestic Biogas Stove: GB/T 3606-2001. State General Administration of Quality Supervision and Inspection and Quarantine of the People's of Republic of China (AQSIQ), No. 9, Madian Donglu Haidian, District Beijing, 100088 , People's Republic of China; 2001.

[30] BIS. IS 8749: 2002. Biogas stove-specification (second revision). Bureau of Indian Standards (BIS), Manak Bhavan, New Delhi, India; 2002.

[31] KEBS. KS 2520: 2013. Domestic Biogas stoves - Specifications; 2013.

[32] Itodo IN, Agyro GE, Yusuf P. Performance evaluation of a biogas stove for cooking in Nigeria. I Energy Southern Africa 2007:18(3):14-8.

[33] Fulford D. Biogas stove design: a short course. Kingdom Bioenergy Ltd.; 1996.

[34] Bajet MA, Paz CB, Bermio JB. Modified stove burner for biogas. Int J Math Eng Technol 2012;4:33-47.

[35] Sasse L, Kellner C, Kimaro, A. Improved biogas unit for developing countries. Deutsche Gesellschaft fur Technische Zusammenarbeit (GTZ), GmbH, Eschborn, Germany; 1991. p. 55-57 and 98.
36] Balasubramaniyam U, Zisengwe LS, Meriggi N, Buysman E. Biogas production in climates with long cold winters. The Netherlands: Wageningen University; 2008. p. 68

[37] Cherubini F, Bargigli S, Ulgiati S. Life cycle assessment (LCA) of waste management strategies: land filling, sorting plant and incineration. Energy $2009 ; 34(12): 2116-23$

[38] Kafle GK, Kim SH. Effects of chemical compositions and ensiling on the biogas productivity and degradation rates of agricultural and food processing byproducts. Bioresour Technol 2013;142:553-61.

[39] Mandal T, Kiran BA, Mandal NK. Determination of the quality of biogas by flame temperature measurement. Energy Convers Manage $1999 ; 40: 1225-8$

[40] Cacua K, Amell A, Cadavid F. Effects of oxygen enriched air on the operation and performance of a diesel-biogas dual fuel engine. Biomass Bioenergy 2012;45:159-67.

[41] Hong Z, Deng GC, Gao LA. Research on the effect of $\mathrm{pH}$ for biogas production. Anhui Agric Sci 2008;36(19):8216-7

[42] Ronghou L, Hao Y, Ye Z, Yuanyuan W, Fei S, Lijuan W. Experimental research on technical parameters of anaerobic fermentation for biogas production. Trans CSAE 2006;22(1):85-8.

[43] Song L, Deng L, Yong Y, Xiaodong P, Zhiyong W. Biogas production potential of manure sheep, duck and rabbit for anaerobic digestion and their characteristics. Trans CSAE 2010;26(10):277-82.

[44] Kalghatgi GT. Blow-out stability of gaseous jet diffusion flames. Part I: In stil air. Combust Sci Technol 1981;26:233-9.

[45] Chao YC, Wu CY, Lee KY, Li YH, Chen RH, Chen TS. Effects of dilution on blowout limits of turbulent jet flames. Combust Sci Technol 2004; 176:1735-53.

[46] Karbassi M. Stability limits of non-premixed flames. Ph.D. thesis. University of Calgary; 1997

[47] Colorado AF, Herrera BA, Amell AA. Performance of a flameless combustion furnace using biogas and natural gas. Bioresour Techno 2010;101(7):2443-9.

[48] Dai W, Qin C, Chen Z, Tong C, Liu P. Experimental studies of flame stability limits of biogas flame. Energy Convers Manage 2012;63:157-61.

49] Hosseini SE, Wahid MA. Biogas utilization: experimental investigation on biogas flameless combustion in lab-scale furnace. Energy Convers Manage 2013;74:426-32.

[50] Rao MS, Singh SP, Singh AK, Sodha MS. Bioenergy conversion studies of the organic fraction of MSW: assessment of ultimate bioenergy production potential of municipal garbage. Appl Energy 2000;66:75-87.

[51] Gas quality. CEN/AFNOR/WG 197. Doc. Number 230 (2010-12-29) and 308 (2012-01-27)

[52] UNE-EN 30-2-1: 1999. Domestic cooking appliances burning gas. Part 2-1: rational use of energy. General. AENOR; 1999.

53] UNE-EN 437: 2003+A1: 2009. Test gases. AENOR; 2009.

[54] UNE-EN ISO 6976: 1995. Natural gas - calculation of calorific values, density, relative density and Wobbe index from composition. AENOR; 1995.

[55] UNE-EN ISO 6141: 2007. Gas analysis - requirements for certificates fo calibration gases and gas mixtures (ISO 6141: 2000). AENOR; 2007.

[56] Khandelwal KC, Gupta VK. Popular summary of the test reports on biogas stoves and lamps prepared by testing institutes in China, India and the Netherlands. SNV Netherlands Development Organisation. The Hague. The Netherlands; 2009.

[57] Hílbert JA. Manual para la producción de biogas. Instituto de Ingeniería Rura (INTA-Castelar)

[58] UNE-EN 30-1-1 (2009)+A2 (2011). Domestic cooking appliances burning gas Part 1-1: Safety. General. AENOR: 2011.

[59] American gas association. Interchangeability of other fuel gases with natura gas. American gas association research bulletin No. 36. Cleveland; 1946.

[60] Urmee T, Gyamfi S. A review of improved cook stove technologies and programs. Renew Sustain Energy Rev 2014;33:625-35.

[61] Kimiti RM, Kamau JN, Kariuki FN. Effect of biogas on cooking efficiency of stoves on small scale biogas plants in Kenya. J Phys Sci Innov 2012;4(December).

[62] Centre for Energy Studies. Institute of Engineering, Tribhuvan University. A study report on efficiency measurement of biogas, kerosene and LPG Stoves. Biogas Support Program, Lalitpur, Nepal; July 2001.

[63] Cardona CA, Amell AA. Laminar burning velocity and interchangeability analysis of biogas/C3H8/H2 with normal and oxygen-enriched air. Int Hydrogen Energy 2013:38:7994-8001.

[64] European gas interchangeability. Williams, Terry. GL industrial services. In: Proceedings of the 24th World Gas Conference, Buenos Aires (Argentina) Curran Associates, Red Hook, NY, 5-9 October, 2009. p. 4654-63.

[65] Laciak M. Properties of artificial gaseous mixtures for their safe use and support the natural gas supply networks. Arch Min Sci 2012;57(2):351-62. 